\title{
Realistic Evaluation as both a science and as a methodology
}

Realistyczna ewaluacja jako nauka i metodologia

\section{Paul Linsley}

University of East Anglia, UK

Paul Linsley: 0000-0002-0726-7635

CORRESPONDING AUTHOR:

Paul Linsley

School for health Sciences, University of East Anglia

Norwich Research Park, Norwich NR4 7TJ

United Kingdom

Phone: +4401603 597132

\begin{abstract}
STRESZCZENIE REALISTYCZNA EWALUACJA JAKO NAUKA I METODOLOGIA
Praca bada cieszącą się coraz większą popularnością metodologię rozwiniętą przez Pawsona i Tilleya [1], która została przez nich nazwana mianem „realistycznej ewaluacji”. Praca przedstawia omówienie metodologii oraz bada podstawę koncepcji, którą jest realizm krytyczny. Artykuł sugeruje, że realistyczna ewaluacja zapewnia przydatne środki do badania zdrowia oraz nauk społecznych poprzez użycie łączonych metod, oraz zawiera wnioski dotyczące tego jak badacz może rozpocząć używanie realistycznej ewaluacji w badaniach.

Słowa kluczowe: realistyczna ewaluacja, realizm krytyczny, łączone metody
\end{abstract}

ABSTRACT REALISTIC EVALUATION AS BOTH A SCIENCE AND AS A METHODOLOGY

This paper examines an increasingly used methodology developed by Pawson and Tilley [1] that they termed, 'Realistic Evaluation'. The paper provides an overview of methodology as well as exploring its underpinning philosophy, that of critical realism. The paper suggests that Realistic Evaluation provides a useful means of exploring the health and social sciences through the use of mixed methods and concludes with how a researcher might go about constructing a Realist Evaluation study.

Key words: $\quad$ Realistic Evaluation, critical realism, mixed-methods

\section{INTRODUCTION}

Philosophy, as a product of human thought, is inherent in our decision making whether or not it appears at a conscious level. By attending to philosophy, researchers are attending to the assumptions on which their enquiry is based, "philosophy makes explicit the knowledge implicit in practice" [2]. The key aspects of philosophical enquiry to be addressed are that of ontology (is there knowledge?), epistemology (if there is knowledge what does that knowledge look like?) and methodology (how do we go about investigating that knowledge?). The first two are reflected in the third and the choice of data collection and analysis when thinking about and undertaking a research study.

Traditionally these questions have been responded to from two divergent paradigms, those of Positivism and Interpretivism [3]. This is because Positivist and Interpretivist paradigms look at the world from different perspectives and as such require different instruments and follow different procedures to collect and analyze the type of data that they desire. An inability to logically reconcile these positions can cause problems for researchers and often results in either philosophical skepticism [4] or more often an approach whereby philosophical groundings are stated but not apparent in practice [5].

Realism recognizes the inadequacies of these dominant approaches; that neither objective truths nor socially constructed interpretations can alone provide sufficient explanation of complex social phenomena. Whilst acknowledging the insights of both Positivism and Interpretivism, yet free from the constraints of either, realism provides a "third way" [6] a 'middle ground' and is now gaining popularity in the health and social care literature as a means of bridging the divide between Positivist and Interpretive approaches. Whilst realism is devoid from any particular paradigm, it provides an ontological framework, in which to conceptualize social issues, and in which mixed methods can be used without resulting in paradigmatic dissonance.

The term 'realist evaluation' is drawn from Pawson and Tilley's seminal work, Realistic Evaluation [1]. It is, as its name suggests, an approach grounded in critical realism, a school of philosophy which asserts that both the material 
and the social worlds are 'real' and can have real effects; and that it is possible to work towards a closer understanding of what causes change [7-9]. The critical part of critical realism reflects a critical social science view; namely that social science should be critical of the practices it studies [10] and holds similarities with a Marxist view that what is apparent on the surface, is often masking an underlying reality. The realist view that knowledge is fallible indicates the possibility that our ideologies may be formed from flawed knowledge [11]. Realism therefore explores the assumptions on which practices are based, not only uncovering false knowledge and beliefs, but providing explanations as to why these beliefs are held. This is a particularly relevant consideration within Health as inequities are continuing to widen, despite our awareness of their existence.

Increasingly, health issues such as obesity, diabetes, and long-term conditions are attributed to avoidable factors such as lifestyle choices and health behaviors, and concerns over sustainability of a universal healthcare system gives rise to debates about where the responsibility for health should lie. This necessitates consideration of the ways in which societal and systemic factors impinge on health decisions, and a recognition that individual actions are rooted in societal contexts. Through studying the real social forces which constrain human action and studying social structures and agency as separate but interrelated entities, it is possible to not only understand the way things are, but how the current state of affairs has emerged [12]. Furthermore, the realist view of complexity acknowledges the interdependency on the part of individuals, healthcare systems and societies in tackling health inequalities [13].

Health and social programs are an attempt to address an existing social problem - that is, to create some level of social change. Realistic evaluation seeks to identify how and why program outcomes are achieved. Before the time that Pawson and Tilley [1] developed Realistic Evaluation, Palmer's research [14] into the behaviors of offenders suggested that, rather than asking what works for offenders as a whole, a more relevant question is,

'Which methods work best for which types of offenders under what conditions or in what type of settings (p. 150) [14].

In their Realistic Evaluation Pawson and Tilley (p. 220) [1] translated this notion, to argue the importance of finding out:

'What worked, for whom in what circumstances?'

Rather than seeking causation and generalization as an end-product as in succession theory, or the 'specification of the constructions held by the multiplicity of stakeholders' (p. 118) [1], to which constructivists are committed, a realist evaluator searches for 'cumulation' (p. 119) [1]. By 'cumulation' they do not mean simply completing a series of studies with reliable evidence that can be applied universally, but the need to develop 'middle-range theories' defined by Merton (p.39) [16]. as:

Theories that lie between the minor but necessary working hypotheses that evolve in abundance during day-to-day research and the all-inclusive systematic efforts to develop a unified theory that will explain all the observed uniformities of social behaviour, social organization and social change.

Pawson and Tilley (p.71) [1] described the logic of realist evaluation as follows:

'The basic task of social inquiry is to explain interesting, puzzling, socially significant regularities. Explanation takes the form of posting some underlying mechanism, which generates the regularity and thus consist of propositions about how the interplay between structure and agency has consisted the regularity. Within realist investigation there is also investigation of how the workings of such mechanisms are contingent and conditional, and thus fired in particular local, historical or institutional contexts.

A realist approach assumes that programs are "theories incarnate". That is, whenever a program is implemented, it is testing a theory about what 'might cause change', even though that theory may not be explicit. One of the tasks of a realist evaluation is therefore to make the theories within a program explicit, by developing clear hypotheses about how, and for whom, programs might 'work'.

Identifying the crucial program mechanisms is only the first step in a realist evaluation. It also always assumes that they will be active only under particular circumstances, that is, contexts [1]. The contexts in which programs operate make a difference to the outcomes they achieve. Contexts describe those features of the conditions in which programs are introduced that are relevant to the operation of the program mechanisms.

Realist explanation is based on the proposition that causal outcomes follow from mechanisms acting in contexts. A realist evaluation cycle involves framing theories which identify and explain regularities, driving hypotheses concerning what might work, for whom in what circumstances, testing these through multi-method data collection and analysis, which can then inform further generalizations and lead to revision of theory and new hypotheses. This means collecting data, not just about program impacts, or the processes of program implementation, but about the specific aspects of program context that might impact on program outcomes, and about the specific mechanisms that might be creating change. This process is articulated and illustrated in the formulation of context, mechanisms, outcomes or CMOs (see diagram below).

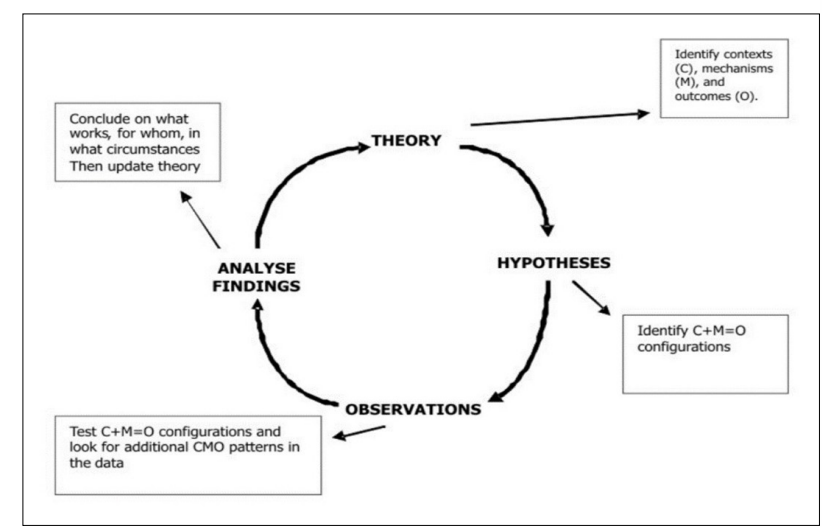

Fig 1. Context, Mechanisms, Outcomes Configuration 
Programs are almost always introduced into multiple contexts, in the sense that mechanisms activated by the interventions will vary and will do so according to saliently different conditions. Program contexts include features such as social, economic and political structures, organizational context, program participants, program staffing, geographical and historical context, and so on. Some factors in the context may enable particular mechanisms to be triggered whilst other aspects of the context may prevent particular mechanisms from being triggered. As such, program outcomes cannot be explained in isolation and often a realistic evaluation will consist of a series of CMOs. Through a measurement of a series of CMOs it should be possible to deduce features of contexts that allow different mechanisms to achieve particular outcomes. In this way, effectiveness of a program is apprehended with an explanation of why the outcomes developed as they did, and how the programme was able to react to other mechanisms, and in what contexts. This analysis provides not only evidence of effectiveness, but also an explanation that helps to develop and to improve both the content and the targeting of future programmes.

To begin evaluating a program using the principles of realistic evaluation, the researcher frames theories in terms of propositions about how the mechanisms are triggered. Pawson and Tilley (p. 88) [1] called such theories, 'folk theories' suggesting that they developed from people's experiences. These are developed further upon analyzing the data derived from the chosen methodology, which may be quantitative or qualitative, or both. Pawson and Tilley [1] argued that it is perfectly possible to carry out realist evaluation using a variety of data collection methods but that the selection should be made with reference to proposed theories. They argue that different stakeholders will have different information and understandings about how programs are supposed to work and whether they in fact do so. Data collection processes (interviews, focus groups, questionnaires and so on) should be constructed to collect the particular information that those stakeholder groups will have, and thereby to refute or refine theories about how and for whom the program 'works. However, as Pawson and Tilley [1] emphasized, the goal of realistic evaluation is not to construct theories per se, but to help program and policy makers in their decision making.

\section{CONCLUSIONS}

Increasingly, researchers are using different approaches to evaluation, whilst many of these maintain an element of outcome evaluation, they also seek to evaluate other elements of the program or intervention. The advantage of using realistic evaluation in research studies, particularly of program evaluation, is that it recognizes that looking at outcomes is not enough; that each program is dependent on the way it is introduced, delivered and managed. It is concerned with what works, for whom, in what circumstances, and that this is better explored through multi method data collection and analysis. In doing so, it acts as a bridge between Positivist and Interpretivist approaches to research in order to gain a fuller understanding of the topic under investigation.

\section{REFERENCES}

1. Pawson R, Tilley N. Realistic Evaluation. London: Sage, 1997.

2. Collier A. Critical Realism: An Introduction to Roy Bhaskar's Philosophy. NY: Verso; 1994.

3. Linsley P, Kane R, Barker J. Evidence-based Practice for Nurses and Healthcare Professionals (4 ${ }^{\text {th }}$ Ed.). London: Sage, 2019.

4. Gascoigne N. Skepticism. London: Routledge, 2014.

5. Nagel T. The View from Nowhere. New York: Oxford University Press, 1986.

6. Wainwright S, Forbes A. Philosophical Problems with Social Science Research on Health Inequalities. Health Care Analysis. 2000; 8(3): 259-277.

7. Bhaskar R. A Realist Theory of Science. Hassocks: Harvester, 1978.

8. Bhaskar R. Reclaiming Reality: A Critical Introduction to Contemporary Philosophy. London: Verso; 1989.

9. Bhaskar R. "Facts and values: theory and practice". [in] Archer MS, Bhaskar R, Collier A, et al. (Eds). Critical Realism: Essential Readings, Routledge. London; 1998, pp. 409-43.

10. Sayer A. Realism and Social Science. London: Sage, 2000.

11. Morgan J, Olsen W. Defining Objectivity in Realist Terms. Objectivity as a SecondOrder 'Bridging' Concept Part II: Bridging to Praxis. Journal of Critical Realism. 2008;7(1): 107-132.

12. Archer MS. Realist Social Theory: The Morphogenetic Approach. Cambridge University Press; 1995.

13. Scambler G. Health inequalities. Sociology of health \& illness. 2011; 34: 130-46. 10.1111/j.1467-9566.2011.01387.x.

14. Palmer T. Martinson revisited. Journal of Research in Crime and Delinquency 1975;12(7): 133-152.

15. Merton R. Social Theory and Social Structure, New York: Free Press, 1968.

Manuscript received: 30.11 .2018

Manuscript received: 30.10.2019 